\title{
The Strategy of the Principal in Improving the Quality of Institutional Education
}

\author{
Ali Muhdlorul Huda ${ }^{1}$, Mauhibur Rokhman ${ }^{2}$ \\ 1,2Institut Pesantren KH. Abdul Chalim Pacet Mojokerto Indonesia \\ e-mail: alimuhdlorulhuda@gmail.com
}

Submitted: 15-08-2021 Revised : 30-10-2021 Accepted: 05-11-2021

\begin{abstract}
This article aims to describe and analyze the planning, implementation, and evaluation of Madrasahs in strengthening the quality of education at MI (Islamic Elementary School) Miftahul Ulum, Kesambenwetan Village, Driyorejo District. This article uses a qualitative research type with a case study design, taking the research location at MI Miftahul Ulum. Methods of data collection are done by (1) interview (2) observation (3) documentation. Data analysis used the Miles and Huberman model: namely data reduction, data presentation, and conclusion drawing. The research findings show that: 1) Madrasah planning in improving the quality of education at MI Miftahul Ulum through a) Internal environmental analysis b) External environment analysis c) strategy selection, 2) Madrasah implementation in improving the quality of basic education, through, a) Tahfidz class programs, b) superior class program c) Extracurricular program The conclusion obtained is that improving the quality of education begins with the commitment of Madrasahs in improving the quality of education, followed by increasing the resources of teachers and education personnel, and principal management and implementation of strategies to improve quality. The quality applied is, though, a) Tahfidz class program, b) superior class program c) Extracurricular program.
\end{abstract}

Keywords: Strategy of Education, Islamic Elementary School, Quality of Education

doi) Https://doi.org/10.54069/attadrib.v4i2.142

How to Cite Huda, A.M Rokhman, M. (2021). Strategy of the Head of Madrasah in Improving the Quality of Institutional Education. Attadrib: Jurnal Pendidikan Guru Madrasab Ibtidaiyah Vol 4(2), 72-80

\section{INTRODUCTION}

National Education has the goal of forming an autonomous organization so that it is able to innovate in education towards an institution that is ethical, reasonable, has positive social communication skills, and has healthy and strong human resources(Anwar, 2021). Through education, a person will compete and motivate himself to be better in all aspects of life. Education is a benchmark for the progress of a country, therefore there is a need for education ranging from kindergarten level to university level education (Abd Hamid et al., 2012; Alda et al., 2020).

National education functions to develop capabilities and shape the character and civilization of a dignified nation in order to educate the nation's life, develop the potential of students to become human beings who believe and fear God Almighty, have noble character, are healthy, knowledgeable, capable, creative, independent, and become a democratic and responsible citizen. Universal education aims to shape the character of a person who believes and fears God Almighty (Calabrese \& Roberts, 2002). 
Competition between educational institutions is indicated by the provision of facilities and infrastructure to support the learning process in schools. One of the efforts to improve the quality of education is through the learning process. Basically the learning process is a process of adding new information and abilities(Al-Musawi et al., 2019; Ciampa, 2015). When thinking about what information and abilities students should have, at that time they also start thinking about what strategies to do so that all information conveyed to students can be accepted effectively and efficiently as new knowledge that will be possessed (Winarsih, 2017). Learning can be carried out formally or informally, both through school and outside of school, so it is hoped that all components of the nation can enjoy education as the primary need of society as contained in the 1945 Indonesian Constitution (UUD).

A quality educational institution is not only seen from the quality of its human resources (HR) graduates but also includes how schools can meet customer needs in accordance with applicable quality standards (Rosidi, 2018; Santosa \& Devi, 2021). Customers in this case are internal customers (educators and education personnel) as well as external customers (students, parents, community and graduates). The quality of education depends on the level of customer satisfaction in using the product. When associated with an educational institution, the quality or not of the educational institution depends on whether or not people are satisfied or the community entrusts their children to the educational institution, or in accordance with the expectations achieved by internal or external customers (Dacholfany, 2018; Fajriana \& Aliyah, 2019).

Schools as institutions where human resources are formed to become human beings with superior personalities in the present and in the future. Elementary school as a level of basic education aims to provide basic knowledge, attitudes, and skills for students. This basic education is further developed to improve the self-quality of students. Schools as educational institutions must have a quality management strategy in order to be able to meet the needs of quality education as an elementary school (Budiya, 2021; Huang et al., 2020).

Improving the quality of educational institutions will only occur effectively if managed through proper management. So far, improving the quality of education tends to be through centralized management (Muslimin \& Kartiko, 2020). So many programs to improve the quality of primary school education are determined and pursued centrally by the central government. Once the various teacher training programs are designed and implemented centrally in order to improve the quality of educational institutions in primary schools. How many dropping library books, textbooks are sought centrally, and elementary schools just receive what has been allocated by the central government (Hamdi, 2019).

As (Hamalik, 2006) opinion, that the importance of improving education to be of higher quality, that is, starting with improving the teaching staff because this is a very basic thing. No matter how many Visions, Missions that have been prepared by experts, the availability of equipment and sufficient costs for educational needs, in the end success depends on performance and how to implement it in the educational process and situation.

To obtain data and information in accordance with the theme and title of the study, the authors took an educational institution, namely MI Miftahul Ulum Driyorejo. This educational institution is able to attract the attention of the public, as evidenced by the largest number of students in Driyorejo District, which is 551 students, and its achievements are increasing every 
year, as evidenced by being the general champion in the quiz event in the Driyorejo sub-district, for example in religious competitions, sports. , intelligence, etc. and also the level of public trust in the school is good, so that there is a lot of interest in the community to send their children to MI Miftahul Ulum Driyorejo so a selection is needed.

The data and information used by the researchers came from educational institutions under the auspices of the Ma'arif Educational Institution, namely MI Miftahul Ulum, Kesambenwetan Village, Driyorejo District. The selection of this Madrasah as research data is because the Madrasah is considered capable of attracting the attention of the public in terms of its superior education and the achievements achieved every year have increased. This can be seen in religious competitions, sports, quizzes, and others, and the level of public trust in the madrasa is good, so the enthusiasm and interest of the community to send their children to MI Miftahul Ulum, Kesambenwetan Village, Driyorejo District is very high.

\section{METHOD}

This article uses a qualitative type of research with the approach used in this research is a case study, which is a system that has boundaries and working parts. is an empirical inquiry that investigates phenomena in real-life contexts, where the boundaries between phenomena and contexts are not clear, and utilizes various sources of evidence. The true function of this approach is to highlight the peculiarities and uniqueness. While the main purpose of using a case study approach is to understand the details of the strategy for improving the quality of education at MI Miftahul Ulum Driyorejo.

The place of this research was conducted at Madrasah Ibtidaiyah (MI) Miftahul Ulum, which is located at Kesamben Wetan Village, RT. 02 RW. 01 Driyorejo District, Gresik Regency. The informants of this study were the head of the Madrasah (Mr. Sulistiyono), the Madrasah Committee (Siti Khodijah), the deputy head of the madrasah for curriculum (Siska) for Student Affairs, (Mrs. Yanus) and several teachers concerned. Data collection techniques with observation, interviews and documentation. The data collection technique is an effort to observe the variables carefully through the methods of observation, interviews and documentation. Data analysis techniques follow the model (Miles et al., 2014) namely by 1) data reduction, 2) data presentation and, 3) verification and drawing conclusions.

\section{RESULT AND DISCUSSION}

\section{Result}

Broadly speaking, the results of this study are as follows: Because what is discussed is planning, implementation and evaluation, the following are the details. The planning of the Head of Madrasah in improving the quality of the institution is as follows: 1) In the planning process, it was found that the head of Madrasah MI Miftahul Ulum Driyorejo conducted an environmental analysis before formulating school programs or activities. 2) Analysis of the internal environment that is observed by the head of Madrasah is the condition of readiness/motivation of educators to achieve students who excel. 3) The external environment analyzed by the head of Madrasah is geographical environment. 4) Taking into account the results of the analysis that has been done, the head of Madrasah coordinates with his team to formulate school programs. 5) The strategy 
chosen by MI Miftahul Ulum Driyorejo in improving the quality of basic education is through the strategy, the Tahfidz Class program, Superior Class and Extracurricular.

Implementation of the Head of Madrasah in Improving the Quality of Education at MI Miftahul Ulum is as follows: 1) Conducting a coordination meeting to select the coordinator or person in charge of each activity program. 2) The activity program that has been formulated is socialized to the committee. Parents or guardians, students and related parties. 3) Tabfidz Class Program and excellent class. 3) Tahfidz program, namely students who want to memorize the Koran. 4) The superior class program is where there are smart students so that they are placed in superior classes.

In what way can you determine or know which students are superior? That is, at the beginning of school entry or admission of new students, the school holds a strict selection, with the results of the selection so that we can find out which students are placed in superior classes and which students are placed in ordinary classes. In addition to the superior class, there is also a special program class, which in the end this class includes potential students, which in the future will also be selected which students will be selected. In this class, students are the class that will be included in various competitions including the Olympics, Nature Lovers, Mathematics, painting competitions, poetry, small dai competitions and so on.

The evaluation of the Head of Madrasah in Improving the Quality of Education at MI Miftahul Ulum Driyorejo is as follows: 1) Implementing PKG (Teacher Activity Program) supervision including academic supervision, activity supervision, etc. 2) Each coordinator or person in charge of the program makes an activity report. 3) Conduct routine evaluations on the learning process through daily test activities, UTS (Middle Semester Examination), UAS (School Final Examination), and tryouts.

Table 1 Research Results, Improving the Quality of Madrasas

\begin{tabular}{|c|c|c|}
\hline No. & Study Focus & Results on the Field \\
\hline \multirow[t]{5}{*}{1.} & Plan & 1. Formulation of all activities for the next year \\
\hline & & 2. Internal Environmental Analysis \\
\hline & & 3. External Environment Analysis \\
\hline & & 4. Coordination with stakeholders \\
\hline & & $\begin{array}{l}\text { 5. Determination of the program to be carried out to improve } \\
\text { quality. In the form of tabfidz class and superior class. }\end{array}$ \\
\hline \multirow[t]{3}{*}{2.} & Implementation & 1. Coordination meeting with the activity coordinator \\
\hline & & 2. Socialization to teachers, students and guardians of students \\
\hline & & 3. Implementation of the Tabfidz class program and superior class \\
\hline \multirow[t]{3}{*}{3.} & Evaluation & $\begin{array}{l}\text { 1. Carry out academic supervision, supervision of PKG (teacher } \\
\text { activity program) }\end{array}$ \\
\hline & & 2. Coordinator conducts work evaluation \\
\hline & & $\begin{array}{l}\text { 3. Daily, weekly, monthly, mid-semester and annual evaluation } \\
\text { reports. }\end{array}$ \\
\hline
\end{tabular}

\section{Discussion}

MI Miftahul Ulum Driyorejo is an elementary school under the auspices of the Ministry of Religion. This madrasa has been able to attract public interest thanks to the achievements that have been achieved, the number of graduates who are accepted into junior high schools has 
increased. Every year the enthusiasm of the community to enroll their children in the school continues to increase.

The strategy carried out by MI Miftahul Ulum Driyorejo is in accordance with the strategic management model of (Wheelen et al., 2017), namely through the interaction of environmental observations, strategy formulation, strategy implementation, and strategy evaluation. Based on the research that has been done by the author in studying the strategy of the Head of Madrasah in improving the quality of education at MI Miftahul Ulum Driyorejo, it can be seen in the discussion below.

\section{Planning of the Head of Madrasah in Improving the Quality of Education at MI Miftahul Ulum Driyorejo}

The steps taken by MI Miftahul Ulum Driyorejo in planning a strategy to improve the quality of education are as follows:

Environmental Analysis: School is an organization that provides public services in the field of education. So the school will deal with the internal and external environment. The internal environment which includes teachers, staff, employees, students and all the resources owned by the school. While the external environment faced is the community, government and so on. The next stage of the strategic planning process carried out by MI Miftahul Ulum Driyorejo is to take into account the environment faced by the school. The internal environment which includes the strengths and weaknesses of the school and the external environment which are opportunities and threats that the school may face.

Internal environment. MI Miftahul Ulum Driyorejo has adequate resources. Currently, there are 32 teachers, this number has been able to meet the needs of teachers at MI Miftahul Ulum Driyorejo. The teacher resources owned by MI Miftahul Ulum Driyorejo are also well trained so that they have high performance. Other resources by MI Miftahul Ulum Driyorejo have adequate school facilities so that they not only support the learning process, but also develop the potential of students according to their interests and talents. Weaknesses in MI Miftahul Ulum Driyorejo include the role of some students who are less disciplined in coming, however, so far MI Miftahul Ulum Driyorejo is able to overcome the problems faced.

External Environment. The external environment analysis conducted by MI Miftahul Ulum Driyorejo is the geographical environment, the polydidikan environment, which is adjacent to SD Alami and SDN 1 Kesamben Wetan, which are at the same level in education. In accordance with what Ricard said that the analysis of the external environment includes the identification and evaluation of social, cultural, political, technological, and trending aspects that may affect the organization. The result of the analysis of the external environment is a number of opportunities that must be exploited by the organization and threats that must be prevented.

Strategy Formulation: Based on the results of the analysis in chapter IV, the strategy chosen by MI Miftahul Ulum Driyorejo is through the tahfidz class program strategy, superior class and extracurricular program.

\section{Implementation of Madrasas in Improving the Quality of Education at MI Miftahul Ulum Driyorejo}


Implementation of Tabfidz Class: MI Miftahul Ulum has a Tabfidz Program which is the main characteristic of this institution. The Tabfidz class is an attraction for the guardians of students to want to send their children to this institution, because there is a guarantee that graduates at Miftahul Ulum have at least memorized 1 juz of the Qur'an. Through this program, students are required to make a memorizing deposit as one of the requirements to receive report cards, both UTS and UAS report cards.

Implementation of the Superior Class Program: MI Miftahul Ulum Driyorejo has the next excellent programs that are the hallmark of the school. It is called the superior class program because through this program MI Miftahul Ulum Driyorejo has special characteristics that make it different from other schools. The flagship class program owned by MI Miftahul Ulum Driyorejo is a superior class program that has its own distinctive learning characteristics. In the current context, the program is prepared to face competition in the competition in the field of science and competition in the global era.

Implementation of Extracurricular Programs: The development of extracurricular processes is carried out to improve the role and competence of students in realizing the vision, mission and goals of the school. The extracurricular activities at MI Miftahul Ulum Driyorejo consist of several activities, namely: 1) Scouts: Held every Saturday morning at 07.00-09.00 WIB. It is a compulsory extracurricular that students from grade VI take. 2) Hadrah and Banjari Arts: Hadrah practice on Saturdays after school is guided by professional teachers in collaboration with Islamic Boarding Schools. This Hadrah group often appears at madrasa events. 3) Drum band: This program is held every Saturday at 07.00 and is followed by grades up to grade VI. 4) Patrol Music: This extracurricular is in the form of music using traditional tools such as gongs, angklung etc. This activity is held every Saturday. 5) Painting \& Calligraphy: Extra painting is held on Saturday afternoons outside of school hours. Supervised by the SBK teacher and followed by class-VI students. 6) Pagar Nusa: This activity was attended by students from class VI who were supervised directly from representatives of MWC Kec. Driyorejo training every Saturday at 10.00 WIB until the end.

\section{Evaluation of Madrasas in Improving the Quality of Education at MI Miftahul Ulum Driyorejo}

The final step in the strategic management process is evaluating results. Evaluation is the process through which organizational activities and performance results are desired. Managers at all levels use performance result information to take corrective action and solve problems. In this case, the evaluation carried out by MI Miftahul Ulum Driyorejo is inseparable from its planning in realizing the quality of education. Evaluation focuses on the programs that have been implemented in preparation for improving the quality of education.

Direct supervision of ongoing programs is a step that is considered appropriate in evaluating implementation activities. Through direct supervision, the Head of Madrasah can see the progress of the implementation of these programs. Through this direct supervision, it is also possible to directly identify the obstacles encountered and find ways to solve them immediately (Devi \& Subiyantoro, 2021; Ilmi et al., 2021).

However, running programs are not always under the direct supervision of the Madrasah Head, each program has a coordinator or person in charge of each program. It's just that 
supervision outside the learning process is carried out by the coordinator or person in charge of school programs or activities(Brooks \& Sungtong, 2016; Fitriani \& Hakim, 2021). Through direct supervision carried out by the coordinator or person in charge, programs or activities in order to improve the quality of effective education. Through direct supervision of all programs or activities, any obstacles encountered in the implementation of programs or activities will be quickly identified and solutions found so that they can become feedback on the implementation of the next program (Savage, 2014).

Implementation of Routine Evaluation of the Learning Process and Activities. Assessment of learning outcomes aims to see the progress of student learning or students in mastering the teaching material that has been studied according to the goals that have been set (Gultom, 2016). MI Miftahul Ulum Driyorejo conducts regular evaluations of the learning process. To find out the extent to which students understand the material provided, the teacher has an obligation to provide an evaluation of the daily test material. So that when students are found who still do not meet the KKM, they can immediately be given guidance and enrichment. In addition to daily tests, the school also provides regular evaluations through UTS, UAS and sixth grade students will get a try out.

Implementation of each activity or at least at the end of the school year. In this evaluation meeting, all coordinators or the person in charge of the teacher will report the results of the implementation of activities or programs under their supervision (Bahrissalim \& Fauzan, 2018). Preparation of Activity Reports and Evaluation Meetings. The preparation of this activity report was carried out by MI Miftahul Ulum Driyorejo in all activities carried out, both by the person in charge or the coordinator of the teachers and students. The purpose of preparing this activity report is to obtain information about the course of school activities that have been completed. Through activity reports or accountability reports. Through these activity reports, it can also be seen whether the process of activities that take place are in accordance with the final results of the activities.

\section{CONCLUSION}

Based on the research results, data exposure, and findings from interviews, observations and documentation as well as discussion of the results of this study, it can be concluded as follows: 1) conduct an environmental analysis before formulating school programs or activities. 2) The analysis of the internal environment that is observed by the Head of Madrasah is to unite the vision and mission of educators in order to develop the Institute into an advanced institution. 3) Analysis of the external environment analyzed by the Head of Madrasah is the surrounding environment. Then, taking into account the results of the analysis that has been done, the Madrasah Principal coordinates with his team to formulate school programs. 4) the selection of strategies chosen by MI Miftahul Ulum Driyorejo in improving the quality of basic education is through strategies, a). Tahfidz class program, b). Excellent class program, c). Extracurricular Program. 5) Implementation of Madrasahs in improving the quality of basic education, namely conducting coordination meetings to select the coordinator or person in charge of each activity program. Then the activity program that has been formulated is socialized to the committee, guardians of students, students and related parties. 6) Then the programs carried out by MI Miftahul Ulum Driyorejo are: Tahfidz Class Program, a superior class program. extracurricular 
program. Evaluation of the Head of Madrasah in improving the quality of education at MI Miftahul Ulum 1) Supervision of school activity programs. As the Head of MI Miftahul Ulum did, namely, a) Supervision of Tahfidz class activities, b) Academic supervision, b extracurricular supervision, evaluation of the process. Each coordinator or person in charge of the program makes a report.

\section{REFERENCES}

Abd Hamid, S. R., Syed Hassan, S., \& Ismail, N. A. (2012). Teaching Quality and Performance Among Experienced Teachers in Malaysia. Australian Journal of Teacher Education, 37(11). https://doi.org/10.14221/ajte.2012v37n11.2

Alda, R., Boholano, H., \& Dayagbil, F. (2020). Teacher Education Institutions in the Philippines towards Education 4.0. International Journal of Learning, Teaching and Educational Research, 19(8), Article 8. http://www.ijlter.org/index.php/ijlter/article/view/2449

Al-Musawi, A. S., Akhzami, S. A., \& Hinai, A. A. (2019). The Omani Distance Learning Program to Teach the Holy Quran: Analytical Descriptive Study. TARBIYA: Journal of Education in Muslim Society, 6(1), 1-9. https://doi.org/10.15408/tjems.v6i1.11182

Anwar, K. (2021). Pancasila Village, Multicultural Education and Moderation of Diversity in Indonesia. Naz̧bruna: Jurnal Pendidikan Islam, 4(2), 221-234. https://doi.org/10.31538/nzh.v4i2.1238

Bahrissalim, B., \& Fauzan, F. (2018). Evaluasi Kurikulum Pelatihan Dalam Meningkatkan Kompetensi Pedagogik Guru Pai Di Balai Diklat Keagamaan Jakarta. Edukasia: Jurnal Penelitian Pendidikan Islam, 13(1), 25-52. https://doi.org/10.21043/edukasia.v13i1.2779

Brooks, M. C., \& Sungtong, E. (2016). 'We still have bombings': School principals and insurgent violence in Southern Thailand. International Journal of Leadership in Education, 19(5), 505533. https://doi.org/10.1080/13603124.2015.1059489

Budiya, B. (2021). Manajemen Pengelolaan Kelas Masa Pandemi di SD Ta'miriyah Surabaya. Attadrib: Jurnal Pendidikan Guru Madrasah Ibtidaiyah, 4(1), 50-54. https://jurnal.staidagresik.ac.id/index.php/attadrib/article/view/129

Calabrese, R. L., \& Roberts, B. (2002). Character, school leadership, and the brain: Learning how to integrate knowledge with behavioral change. International Journal of Educational Management, 16(5), 229-238. https://doi.org/10.1108/09513540210434603

Ciampa, K. (2015). An investigation of teacher candidates' questions and concerns about occasional teaching. Journal of Applied Research in Higher Education, 7(2), 146-163. https://doi.org/10.1108/JARHE-06-2013-0026

Dacholfany, M. I. (2018). Pemberdayaan Masyarakat dalam Meningkatkan Mutu Pendidikan Non-Formal. Tapis: Jurnal Penelitian Ilmiah, 2(1), 43-74.

Devi, A. D., \& Subiyantoro, S. (2021). Implementation of Democratic Leadership Style and Transformational Head of Madrasah in Improving The Quality. Nidhomul Haq: Jurnal Manajemen Pendidikan Islam, 6(1), 14-26. https://doi.org/10.31538/ndh.v6i1.1162

Fajriana, A. W., \& Aliyah, M. A. (2019). Tantangan Guru dalam Meningkatan Mutu Pendidikan Agama Islam Di Era Melenial. Nað̧hruna: Jurnal Pendidikan Islam, 2(2), 246-265. https://doi.org/10.31538/nzh.v2i2.324 
Fitriani, M. I., \& Hakim, M. V. F. (2021). Principal Leadership Patterns in Collaborating With School Committee. Nidhomul Haq: Jurnal Manajemen Pendidikan Islam, 6(1), 194-205. https://doi.org/10.31538/ndh.v6i1.1384

Gultom, E. (2016). Assessment and evaluation in EFL teaching and learning. Proceedings of ISELT FBS Universitas Negeri Padang, 4(1), 190-198.

Hamalik, O. (2006). Manajemen pengembangan kurikulum. Sekolah Pascasarjana Universitas Pendidikan Indonesia dengan PT Remaja Rosdakarya.

Hamdi, A. (2019). Manajemen Mutu Program Diniyah Pada Pondok Pesantren MuhammadIyah Lamongan. Nidhomul Haq: Jurnal Manajemen Pendidikan Islam, 4(2), 247-258. https://doi.org/10.31538/ndh.v4i2.463

Huang, S.-Y., Kuo, Y.-H., \& Chen, H.-C. (2020). Applying digital escape rooms infused with science teaching in elementary school: Learning performance, learning motivation, and problem-solving ability. Thinking Skills and Creativity, 37, 100681. https://doi.org/10.1016/j.tsc.2020.100681

Ilmi, M. U., Setiawan, F., Hikmah, M. N., Kharisma, A., Feryawan, D., \& Hanafie, A. A. (2021). The Basic Concepts of Evaluation and Its Implementation in IRE Lessons in The Pandemic Era. Tafkir: Interdisciplinary Journal of Islamic Education, 2(2), 175-190. https://doi.org/10.31538/tijie.v2i2.50

Muslimin, T. A., \& Kartiko, A. (2020). Pengaruh Sarana dan Prasarana Terhadap Mutu Pendidikan di Madrasah Bertaraf Internasional Nurul Ummah Pacet Mojokerto. Munaddhomah: Jurnal Manajemen Pendidikan Islam, 1(2), 75-87. https://pasca.jurnalikhac.ac.id/index.php/munaddhomah/article/view/30

Rosidi, I. (2018). Pengembangan SDM Dalam Pembentukan Karakter Santri di Lembaga Pengabdian pada Masyarakat (LPM) Pondok Pesantren Wahid Hasyim Yogyakarta. TA'LIM: Jurnal Studi Pendidikan Islam, 1(1), 106-120. http://ejurnal.unisda.ac.id/index.php/talim/article/view/637

Santosa, S., \& Devi, A. D. (2021). The Problematics Online Lectures on Human Resource Management Courses (HRM) at The Islamic College Level. Ną̧bruna: Jurnal Pendidikan Islam, 4(2), 261-271. https://doi.org/10.31538/nzh.v4i2.1452

Savage, J. (2014). Lesson Planning: Key concepts and skills for teachers. Routledge.

Wheelen, T. L., Hunger, J. D., Hoffman, A. N., \& Bamford, C. E. (2017). Strategic management and business policy (Vol. 55). pearson Boston, MA.

Winarsih, S. (2017). Kebijakan dan Implementasi Manajemen Pendidikan Tinggi dalam Meningkatkan Mutu Pendidikan. Cendekia: Jurnal Kependidikan Dan Kemasyarakatan, 15(2), 51-66. https://doi.org/10.21154/cendekia.v15i2.1005 